\title{
Population structure of the lancelet Branchiostoma caribaeum (Cephalochordata: Branchiostomidae) in the Baía de Guanabara, Rio de Janeiro, southeastern Brazil
}

\author{
Luis F. B. da Silva '; Marcos Tavares ${ }^{2} \&$ Abilio Soares-Gomes 1,3 \\ ${ }^{1}$ Departamento de Biologia Marinha, Universidade Federal Fluminense. Caixa Postal 100.644, 24001-970 Niterói, \\ Rio de Janeiro, Brasil. \\ ${ }^{2}$ Museu de Zoologia, Universidade de São Paulo. Avenida Nazareth, 04263-000 São Paulo, São Paulo, Brasil. \\ ${ }^{3}$ Corresponding author. E-mail: abiliosg@vm.uff.br
}

\begin{abstract}
Population structure of the lancelet Branchiostoma caribaeum Sandevall, 1853 was studied in four surveys, corresponding to austral seasons, in a tropical bay, southeast of Brazil. Abundance was higher in the spring and was positively correlated to coarse sediments, limiting its occurrence to some sectors of the sampling area. Body length and biomass differed seasonally but not between sexes. Sexually mature individuals occurred in all seasons, suggesting continuous breeding that is typical of tropical species. Variation in the frequency of small specimens indicates temporal differences in the intensity of breeding. The body length of recruits differed from other population of lancelets and the small length which B. caribaeum attained sexual maturity in Guanabara Bay may be related to local environmental stress or the great availability of food.

KEY WORDS. Amphioxus; autoecology; macrobenthos; marine invertebrates; soft-bottoms; sublittoral.
\end{abstract}

\begin{abstract}
RESUMO. Estrutura populacional do anfioxo Branchiostoma caribaeum (Cephalochordata: Branchiostomidae) na Baía de Guanabara, sudeste do Brasil. A estrutura populacional do anfioxo Branchiostoma caribaeum Sandevall, 1853 foi analisada em quatro campanhas abrangendo todas as estações do ano, na Baía de Guanabara, sudeste do Brasil. A abundância de indivíduos foi maior na primavera e positivamente correlacionada com sedimentos grossos, tendo sua distribuição limitada a alguns setores da área amostral. O tamanho corpóreo e a biomassa diferiram sazonalmente, mas não entre os sexos. Indivíduos sexualmente maduros ocorreram em todas as estações do ano, sugerindo uma reprodução contínua, típica de espécies tropicais. Variações na frequiência de ocorrência de espécimes pequenos indicaram diferenças temporais na intensidade da reprodução. $O$ tamanho corpóreo dos recrutas diferiu de populações de anfioxos de outros locais. O menor tamanho em que B. caribaeum atinge a maturidade sexual na Baía da Guanabara pode estar relacionada ao estresse ambiental ou à grande disponibilidade de alimento do local.
\end{abstract}

PALAVRAS-CHAVE. Anfioxos; auto-ecologia; invertebrados marinhos; macrobentos; sedimentos não-consolidados; sublitoral.

Benthic species are key indicators of estuarine environmental status, responding predictably to many kinds of natural and human-induced disturbances (Thompson et al. 2003, Venturini et al. 2004). Polychaets, mollusks, crustaceans and nematodes are the most common animals in marine soft-bottoms. However, other groups, such as the lancelets (also named amphioxus), dominate numerically some bottoms, having a putative important role in the structure and function of those habitats (Gosselck 1975, Light 1923, Stokes 1996). Their larvae could also reach high densities in the plankton during reproductive events (Boschung \& SHAW 1988). Due to its gregariousness in the benthos system, the habitats where they occur are named "amphioxus sands".

Lancelets are endobenthic organisms that live in coarse sediments, from intertidal to sublittoral bottoms, feeding mainly on plankton and microphytobenthos (Bigelow \& Farfante 1948, RiISGard \& Svane 1999), being important food items for fishes and crustaceans (STOKes \& Holland 1996). It is possible that lancelets play a significant role in the transference of microbial production to higher trophic levels due to their feeding mode (RUPPERT et al. 2000).

Most lancelets have sub-tropical and tropical occurrence but most population and reproductive studies were conducted on temperate species (STOKES \& Holland 1996). Branchiostoma caribaeum Sandevall, 1853 (Branchiostomidae) is the only benthic lancelet species that occur in Brazilian waters (Poss \& Boschung 1996) and very little is known about its occurrence. This work describes some aspects of the population structure and spatial distribution of B. caribaeum from Baía de Guanabara, comparing with populations worldwide. 


\section{MATERIAL AND METHODS}

\section{Study Area}

Baía de Guanabara (BG), located at $23^{\circ} 50^{\prime} \mathrm{S}, 43^{\circ} 08^{\prime} \mathrm{W}$, is a $384 \mathrm{~km}^{2}$ eutrophic coastal bay in southeastern Brazil, impacted by the heavy discharge of both industrial and domestic waste from the Rio de Janeiro metropolitan area and its drainage basin. High inputs of heavy metals, petroleum hydrocarbons and toxic chemical compounds enter the bay daily, especially in the inner portion, accumulating in the bottom sediments (KJERFVE et al. 1997). However, these pollutants seem to be buried in anoxic sediments and therefore, unavailable to biological uptake (CARvalHo et al. 1992).

The bay experiences a large spatial and temporal variability of its water quality, mainly caused by circulation patterns and pollution foci (KJERFve et al. 1997). Circulation is controlled by tides and winds, allowing water inflow from the ocean through the bottom layers. As described by KJERFve et al. (2001), BG has a complex bathymetry with a $400 \mathrm{~m}$ wide central channel, which stretches from the mouth (1.6 km wide) more than $5 \mathrm{~km}$ into the bay, and is defined by the $30 \mathrm{~m}$ isobath. The channel rapidly becomes shallower further into the bay, being $1 \mathrm{~m}$ depth in the inner portion. Because of the intense mud sedimentation, the mean depth in the bay is only $5.7 \mathrm{~m}$.

According to Paranhos et al. (1995) and KJERFVe et al. (2001), the worst water quality of BG is indicated by average faecal coliform counts higher than $1,000 \mathrm{ml}^{-1}$ and by the average chlorophyll concentration exceeding $130 \mathrm{\mu g} \mathrm{l}^{-1}$ in the inner bay, the most critical zone, in response to high nutrient loading. Sediments are not evenly distributed at the bottom, predominating mud at the inner areas and sand near the mouth (BAPTISTA-Neto et al. 2006). As a result of increasing pollution levels and poor circulation towards the inner region, the sediments in this area present oxygen depletion, becoming anoxic during the wet season (Mendes et al. 2007).

\section{Sampling design and laboratory analysis}

Samplings were taken in four oceanographic surveys with three-month intervals, according to austral seasons, in fall and spring of 2000 and summer and winter of 2001. A triplicate sample was taken with a $0.1 \mathrm{~m}^{2}$ van Veen grab in 38 sampling stations. The sampling stations were grouped into inner (stations 1-14), intermediary (stations 15-26), and outer sector (stations 27-38) in relation to natural hydrodynamic characteristics and pollution intensity established in previous work (MENDES et al. 2006, 2007) (Fig. 1).

Sediment samples were sieved out through a $1.0 \mathrm{~mm}$ mesh size and the lancelets sorted under stereomicroscope. Taxonomic determination was based on the revision work of Poss \& Boschung (1996). The Frequency of Occurrence (FO) of the lancelets was calculated for each of the three sectors of the study area. Depending on FO values, the lancelets were classified as constant $(\mathrm{F}>50 \%)$, common $(10 \%<\mathrm{F}>50 \%)$ or rare $(\mathrm{F}$

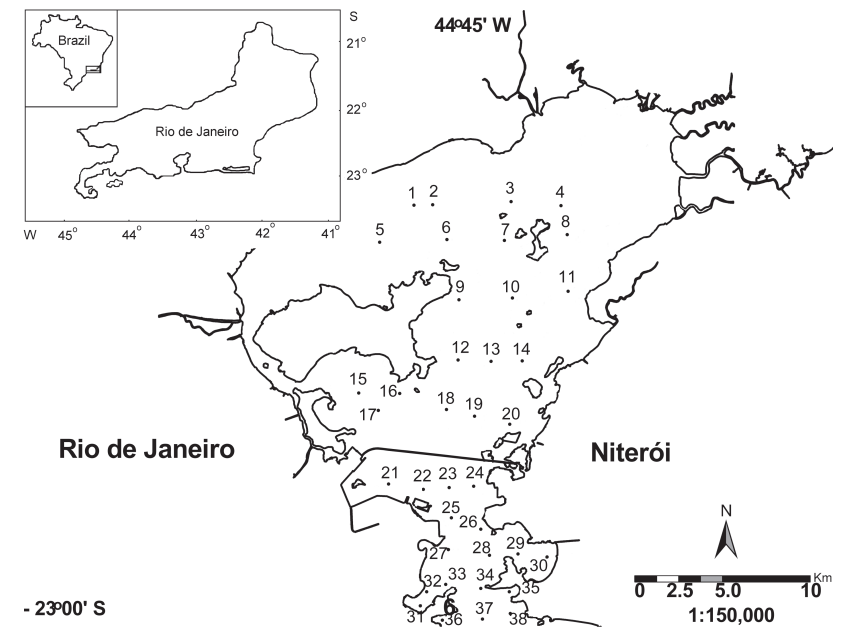

Figure 1. Geographic location and distribution of sampling stations at Baía de Guanabara.

$<10 \%)$. Density, wet weight biomass and the body length were determined for each sample.

Organisms were fixed in $4 \%$ formalin and preserved in $70 \%$ ethanol with glycerin. Because lancelets did not show external sexual dimorphism, sexes were determined by inspection of gonad colors under a stereomicroscope (white in males and orange or red in females. Samples were stored in dark to avoid loss of color. One side of the body wall was randomly choose to observe under stereomicroscope by transparency. A gonad index was used to infer the reproductive development of the population. The index used was the Proxy Gonad Index (PGI), proposed by STOKEs \& Holland (1996) and calculated by the following formula: PGI = Gl.Gw.Gh.k/Bwt, where GI is the gonad length, Gw the gonad width, Gh the gonad height, Bwt the total body weight, and $\mathrm{k}$ the constant $2.9 \times 10^{-6}$. Specimens below $15 \mathrm{~mm}$ had no detectable gonads or very tiny ones and, therefore, sex and PGI could not be determined.

Statistical differences in body length and wet weight biomass among seasons were verified by non-parametric KruskallWallis test. Chi-square test was employed to verify the hypothesis that sex-ratio is 1:1. The relationship between body length and wet weight biomass was analyzed by Pearson correlation coefficient and fitting to a polynomial regression.

Sediment samples were analyzed for grain size distribution, organic matter and carbonate content. The methods of mechanical dry sieving and decantation described by TANNER (1995) were used to determine the grain size fractions. The percentage of total organic matter was determined by loss of mass on ignition and sediment samples were oven-dried at $105^{\circ} \mathrm{C}$ for 12 hours and subsequently ashed at $500^{\circ} \mathrm{C}$ for four hours. Biodetritic carbonate $\left(\mathrm{CaCO}_{3}\right)$ was obtained by $\mathrm{HCl} 10 \%$ attack. The relationship between lancelets density and sediment abiotic variables were determined by multivariate exploratory analysis. Normalized mean values of lancelets density, fine grain fraction, sand 
grain fraction, gravel grain fraction, carbonate and organic matter content were organized in a data matrix to have similarities between stations calculated by Euclidean Distance. Similarity matrix was used to run a Multidimensional Scaling Analysis, using Primer 6 software and results were showed as ordination plots.

\section{RESULTS}

Branchiostoma caribaeum in BG was a rare species in the inner sector while in the intermediary and outer sectors it was constant. Abundance was higher in spring and in the outer sector (Fig. 2). Considering the whole sampling design, the species showed a highly aggregated and patchy distribution reaching a maximum of 38 ind. $0.1 \mathrm{~m}^{-2}$.

Body length ranged from 3.30 to $50.90 \mathrm{~mm}$, with no statistical difference between sexes. Also, wet weight biomass was not statistically different between sexes, ranging from 0.0001 to 0.1284 g. Length and wet weight biomass differed statistically among seasons (KW $=30.9, \mathrm{p}<0.001)$. A visual inspection of the length frequency distribution histogram showed the abundance of specimens below $15 \mathrm{~cm}$ (with no conspicuous gonad; presumably juveniles) was higher in the winter (Fig. 3). Length and wet weight biomass was highly positively correlated $(\mathrm{R}=$ $0.82 \mathrm{p}<0.01$ ), showing a polynomial relationship (Fig. 4).

According to the Chi-square test results, sex-ratio did not depart statistically from 1:1. Sexually mature individuals, both male and female, occurred in all seasons. The majority of individuals bearing conspicuous gonads was between 25 and 35 $\mathrm{mm}$ long. The smallest mature male and female were 16.85 and $21.44 \mathrm{~mm}$, respectively (Fig. 5). The PGI increased from fall to summer and decreased in winter (Fig. 6). Sexually mature individuals were found in all seasons but their relative occurrence was higher in winter (Fig. 7).

Ordination plots of lancelets' density and sediment abiotic variables showed that their occurrence and abundance in BG is positively related to coarse sediments (sand and gravel) and carbonate content, and negatively related to fine grains and organic matter content. Those plots also showed that lancelets are more abundant in the outer sector of the bay (Fig. 8).

\section{DISCUSSION}

The occurrence of lancelets in BG is restricted to coarse sediments, as reported worldwide (Wевв 1955, Boschung \& Gunter 1962, Gosselck 1975, Stokes 1996, Yamaguchi \& Henmi 2003, Dolbeth et al. 2006). It seems that sediment type is the main abiotic variable that drives lancelet distribution. In the inner sector of BG, where they have a rare occurrence, they were found in patches of coarse sediments. In the outer sector, where the hydrodynamics is more intense, coarse sediments are widespread, favoring the establishment of B. caribaeum. No experimental work has been done to elucidate that relationship with coarse sediments, which could be a collateral effect of the necessity of being located in areas of strong hydrodynamics to favor food availability.

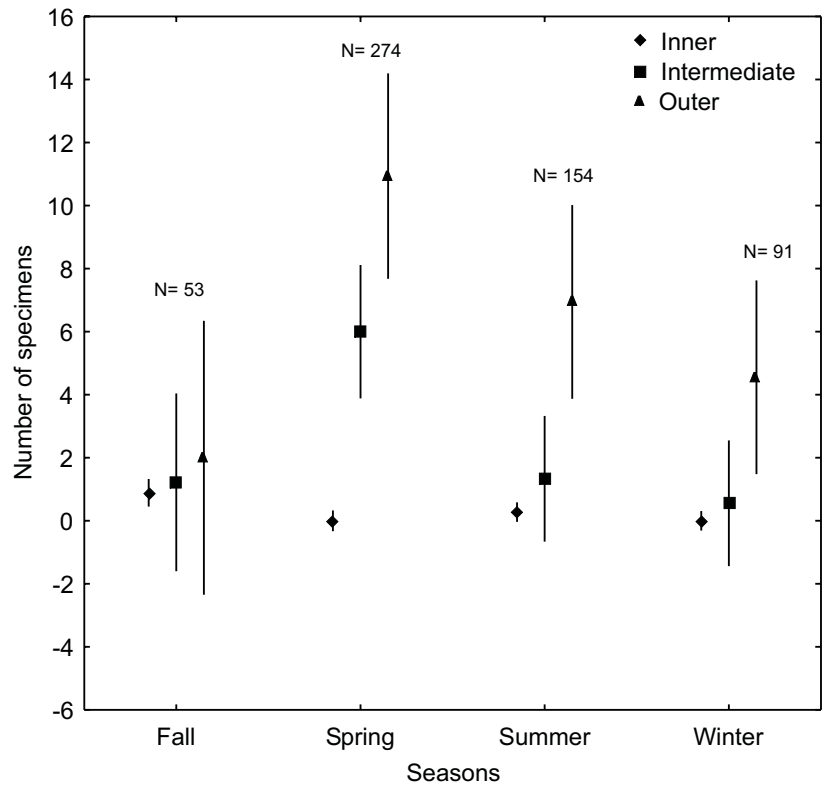

Figure 2. Mean abundance ( \pm standard error) per $0.1 \mathrm{~m}^{-2}$ of $B$. caribaeum in each sector and seasons at Baía de Guanabara. (N) Number of individuals sampled.

Lancelets in BG could reach high densities. Extrapolating the sampling area $\left(0.1 \mathrm{~m}^{2}\right)$ to a square meter area, the maximum density found was about 3,800 ind. $\mathrm{m}^{-2}$. This value is between the maximum densities reported to $B$. floridae Hubbs, 1922 in Florida - 1,200 ind. $\mathrm{m}^{-2}$ (Stокеs 1996), and B. senegalensis Webb, 1955 in Spain - 9,000 ind.m² (Gosselck 1975). Being a filterfeeding animal, those high densities should be supported by the high concentrations of phytoplankton and bacteria in the water of BG (KJERFVe et al. 1997, PARAnhos et al. 1995). However, the sampling design adopted in this work did not allow recognition of the extension of that "amphioxus sand" in the bay to infer about the role of lancelets in the transference of pelagic production in the local food web, as suggested by RupPERT et al. (2000). We suppose that such transference is stronger in the outer sector of the bay, where coarse sediments are widespread (BAPTISTANeto et al. 2006) and lancelets have a constant occurrence. Nevertheless, densities reported in the literature should be viewed with caution because they are extrapolations from areas of sampling devices. Lancelets could never reach those densities in nature since they have a patchy distribution and most sampling designs are not made to determine the extension of those patches.

Endogenous and exogenous factors have been related to reproduction. Among exogenous factors, experimental results by FuENTES (2004) showed that water temperature could control the breeding season of lancelets, and field works by Sтокеs (1996) and Yamaguchi \& Henmi (2003) reported that B. floridae and $B$. balcheri Gray, 1847 breed in warmer season. In BG, water temperature did not show a seasonal variation, raining being the most important environmental change in the bay between sum- 

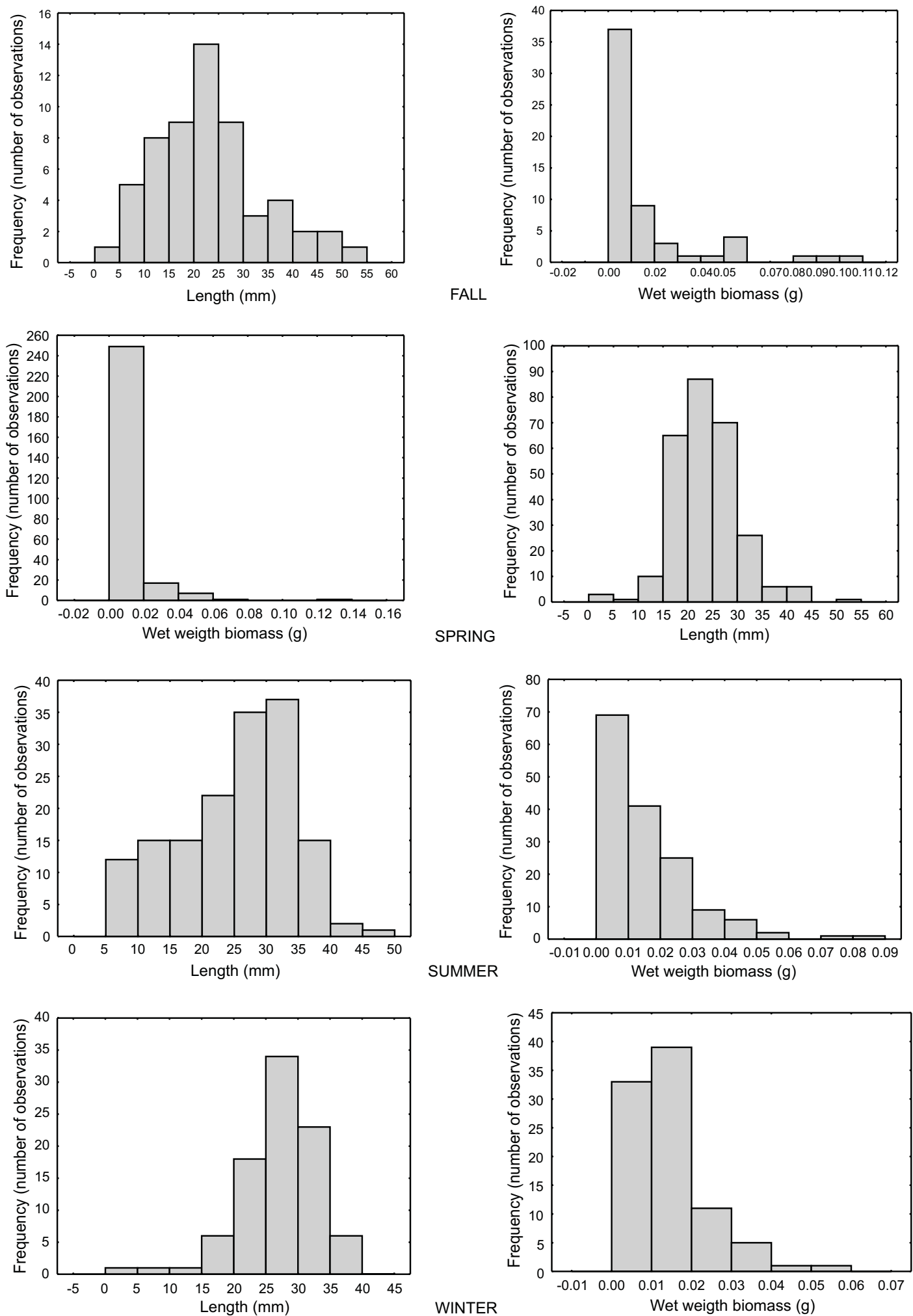

Figure 3. Frequency distribution of body length and wet weight biomass of B. caribaeum in each season at Baía de Guanabara. 

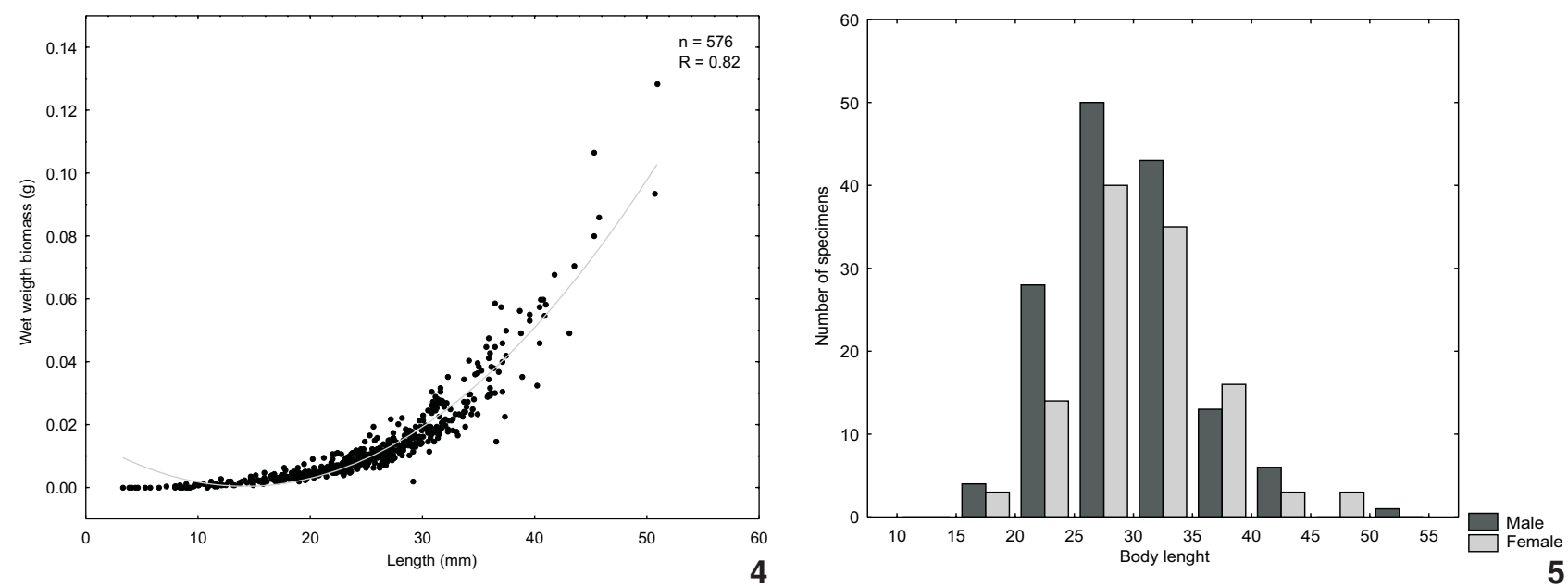

Figures 4-5. (4) Relationship between body length and wet weight biomass of $B$. caribaeum from Baía de Guanabara. (R) Pearson linear correlation coefficient. (5) Body length frequency distribution of male and female specimens of $B$. caribaeum with matured gonads at Baía de Guanabara.

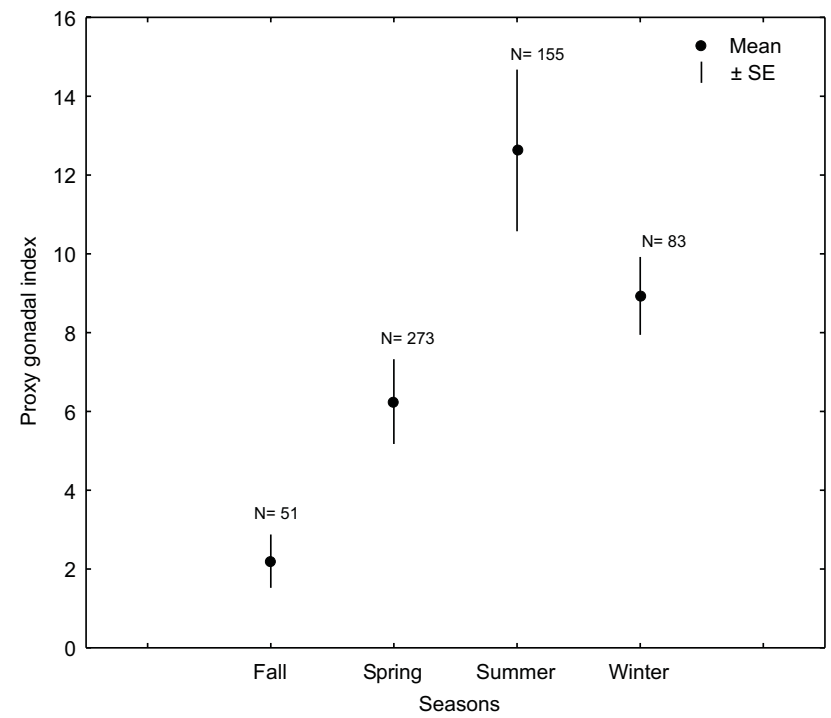

Figure 6. Proxy gonadal index of B. caribaeum in each season at Baía de Guanabara.

mer (wet season) and winter (dry season). However, as a result of the small water residence time within the bay, salinity did not change expressively, except near the mouth of rivers (KJERFVE et al. 1997). In spite of the variations observed in the gonad index of B. cariabaeum in BG, sexually mature individuals occurred in all seasons, suggesting a continuous breeding, typical of tropical species, although an expressive variation in the relative abundance of mature specimens was observed among seasons (from 25 to $60 \%$, in fall and winter, respectively). The frequency of individuals in length categories also showed variations among seasons, the smallest classes being more abundant

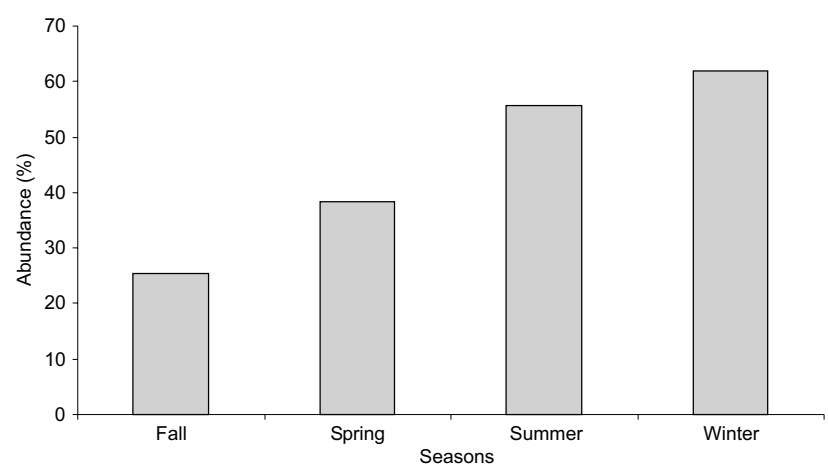

Figure 7. Percentual abundance of $B$. caribaeum mature specimens in each season at Baía de Guanabara.

in the summer. The size classes among 20 and $40 \mathrm{~mm}$ were the more abundant in all surveys while individuals greater than 40 $\mathrm{mm}$ were not found in the winter. Such variations could reflect differences in the intensity of breeding in the local lancelets population. In the northeast of Brazil ( $\left.7^{\circ} \mathrm{S}\right)$, Alves et al. (2001) also found sexually matured specimens occurring along the year but a different pattern of variation, the higher abundance of juveniles in winter and gonads more developed in summer.

The smallest body length is inferred as the length of recruitment (Henmi \& Yamaguchi 2003, Dolbeth et al. 2006). According to that, the size $B$. caribaeum recruits in $B G(3.3 \mathrm{~mm})$ is quite similar to $B$. floridae ( $4 \mathrm{~mm}$ ) from Tampa bay (STOKEs 1996) but different of B. balcheri $(7 \mathrm{~mm})$ from Japan (Henmi \& YAMAGUCHI 2003) and of B. caribaeum (7 mm) from the northeast of Brazil (Alves et al. 2001). Differences in the minimum size could be related to sampling and sorting methods and in the maximum size to food availability, among other variables. 

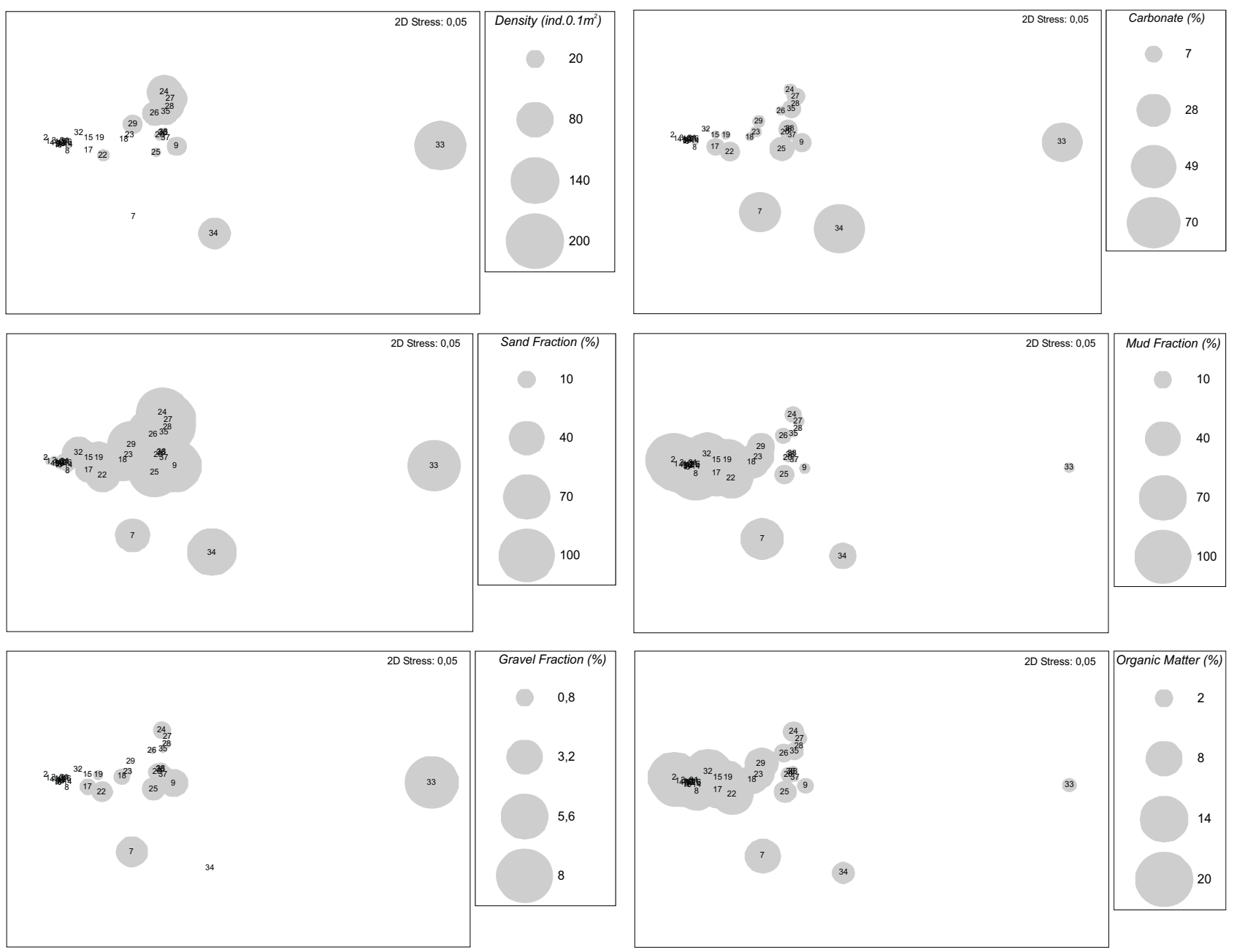

Figure 8. MDS ordination plots of densities of B. caribaeum (a); sand fraction (b); gravel fraction (c); carbonate content (d); mud fraction (e), and organic matter content (f) at Baía de Guanabara.

The size classes between 3.3 and $15 \mathrm{~mm}$ were less abundant in the winter indicating a less intense recruitment in that time.

Specimens below $15 \mathrm{~mm}$ had no detectable gonads indicating the size at the onset of sexual maturity. Values reported in the literature range from 18 to $40 \mathrm{~mm}$ for $B$. floridae and $B$. lanceolatum, respectively (STOKEs 1996, Dolbeth et al. 2006). The smaller length which B. caribaeum attained sexual maturity in BG may be related to local environmental stress or to favorable feeding conditions that could lead to individuals maturing earlier (Kjesbu 1994, Lucas \& Lawes 1998, Yoneda \& Wright 2005).

\section{ACKNOWLEDGEMENTS}

Financial support for this study was granted by the Brazilian National Council for Research $(\mathrm{CNPq})$ and FAPERJ, for which we are very grateful.

\section{LITERATURE CITED}

Alves M.S.; A.C. Lins-e-Silva; L.M. Silva \& L.O. Melo 2001. Cephalochordata do Estuario do Rio Paripe, Itamaracá, Pernambuco. Tropical Oceanography 29 (2): 129-138.

Baptista-Neto J.A.; F.X. Gingele; T. Leipe \& I. Brehme. 2006. Spatial distribution of heavy metals in surficial sediments from Guanabara Bay: Rio de Janeiro, Brazil. Environmental Geology 49: 1051-1063.

Bigelow H.B. \& I.P. Farfante. 1948. Lancelets. Fishes of the Western North Atlantic. Memoir of the Sears Fundation for Marine Research 1 (17): 1-28.

Boschung H.T. \& C. GunTER. 1962. Distribution and variation of Branchiostoma caribaeum in Mississippi Sound. Tulane Studies of Zoology 9: 245-247.

Boschung H.T. \& R.F. SHAw. 1988. Occurrence of planktonic 
lancelets from Louisiana's continental shelf, with a review of pelagic Branchiostoma (Order Amphioxi). Bulletin of Marine Science 43 (2): 229-240.

Carvalho C.E.V. \& L.D. LaCerDa. 1992. Heavy metal in Guanabara bay biota: Why such low concentration? Journal of the Brazilian Association for Advance of Science 44 (2/3): 184186.

Dolbeth M.; I. Viegas.; J.C. Martinho; J.C. Marques \& M.A. ParDAL. 2006. Population structure and species dynamics of Spisula solida, Diogenes pugilator and Branchiostoma lanceolatum along a temporal-spatial gradient in the south coast of Portugal. Estuarine, Coastal and Shelf Science 66: 168-176.

Fuentes M.; M. Schubert; D. Dalfo; S. Candiani; E. Benito; J. Gardenyes; L. Godoy.; F. Moret; M. Illas; I. Patten; M. Pestarino; J.G. Fernandez; R. Albalat; V. Laudet; P. Vernier \& H. Escriva. 2004. Preliminary observations on the spawning conditions of the European amphioxus (Branchiostoma lanceolatum) in captivity. Journal of Experimental Zoology 302B: 384-391.

GosselK F. 1975. The distribution of Branchiostoma senegalensis (Acrania: Branchiostomidae) in the off-shoe shelf region off North-West Africa. Hydrobiologia 60: 199-207.

KJerfve B.; C.H.A. Ribeiro; G.T.M. Dias; A.M. Filipo \& V.S. QuaresMA. 1997. Oceanographic characteristics of an impacted coastal bay: baía de Guanabara, Rio de Janeiro, Brazil. Continental Shelf Research 17 (13), 1609-1643.

Kjerfve B.; L.D. Lacerda \& G.T.M. Dias. 2001. Baía de Guanabara, Rio de Janeiro, Brazil, p. 107-117. In: U. SeEliger \& B. KJeRfVe (Eds). Coastal marine ecosystems of Latin America. Berlin, Springer, XXVI+385p.

KJesbu, O.S. 1994. Timing of start of spawning in Atlantic cod (Gadus morhua) females in relation to vitelogenesis oocyte diameter, temperature, fish length and condition. Journal of Fish Biology 45: 719-735.

Light S.F. 1923. Amphioxus fisheries near the University of Amoy, China. Science 58: 57-60.

LuCAS, C.H. \& Lawes, S. 1998. Sexual reproduction of the scyphomedusa Aurelia aurita in relation to temperatue and variable food supply. Marine Biology 131 (4): 629-638.

Mendes C.L.T.; M. Tavares \& A. Soares-Gomes. 2006. Seasonal and spatial distribution of sublittoral soft-bottom mollusks assemblages at Guanabara bay, Rio de Janeiro, Brazil. Journal of Coastal Research 39 (SI): 1877-1881.

Mendes C.L.T.; M. Tavares \& A. Soares-Gomes. 2007. Taxonomic sufficiency for soft-bottom subllitoral mollusks assemblages in a tropical estuary, Guanabara Bay, Southeast Brazil. Marine Pollution Bulletin 54 (4): 377-384.

Paranhos R.; S.M. Nascimento \& L.M. Mayr. 1995. On the faecal pollution in Guanabara bay. Fresenius Environmental Bulletin 4: 352-357.

Poss S. \& H.T. Boschung. 1996. Lancelets (Cephalochordata: Branchiostomidae): How many species are valid. Israel Journal of Zoology 42: 13-60.

RiIsgrad H.U. \& I. Svane. 1999. Filter feeding in lancelets (amphioxus), Branchiostoma lanceolatum. Invertebrate Biology 118 (4): 423-432.

Ruppert E.E.; T.R. Nash \& A.J. Smith. 2000. The size range of suspended particles trapped and ingested by the filterfeeding lancelet Branchiostoma floridae (Cephalochordata: Acrania). Journal of the Marine Biological Association of United Kingdom 80: 329-332.

STOKES M.D. 1996. Larval settlement, post-settlement growth and secondary production of the Florida lancelet (= amphioxus) Branchiostoma floridae. Marine Ecology Progress Series 130: 71-84.

Stokes M.D. \& N.D. Holland. 1996. Reproduction of the Florida lancelet (Branchiostoma floridae): spawning patterns and fluctuations in gonad indexes and nutritional reserves. Invertebrate Biology 115 (4): 349-359.

TANNER W.F. 1995. Environmental clastic granulometry. Florida Geological Survey Special Publication 40: 1-142.

Thompson, B.W; M.J. Riddle \& J.S. Stark. 2003. Cost-efficient methods for marine pollution monitoring at Casey Station, east Antarctica: the choice of sieve mesh-size and taxonomic resolution. Marine Pollution Bulletin 46: 232-243.

Venturini, N.; P. Muniz. \& M. Rodrigues. 2004. Macrobenthic subtidal communities in relation to sediment pollution: the phylum-level meta-analysis approach in a south-eastern coastal region of South America. Marine Biology 144: 119-126.

Wевв J.E. 1955. On the lancelets of West Africa. Proceedings of the Zoological Society of London 125: 421-443.

Yamagushi T. \& Y. Henmi. 2003. Biology of amphioxus, Branchiostoma belqueri in the Ariake Sea, in Japan II. Reproduction. Zoology Science 20: 907-918.

Yoneda, M. \& P.J. Wright. 2005. Effects of temperature and food availability on reproductive investment of first-time spawning male Atlantic cod, Gadus morhua. ICES Journal of Marine Science 62: 1387-1393.

Submitted: 20.V.2008; Accepted: 01.XII.2008.

Editorial responsibility: Maria Lúcia Negreiros-Fransozo 